\title{
An Empirical Study on Needs Analysis of College Business English Course
}

\author{
Yan $\mathrm{Wu}$ (Corresponding author) \\ College of Foreign Languages, Hebei United University \\ Tangshan 063009, China \\ Tel: 13931553695 E-mail: helenawy2010@126.com
}

\author{
Received: October 17, 2011 Accepted: October 27, 2011 Published: April 1, 2012 \\ doi:10.5539/ies.v5n2p216 \\ URL: http://dx.doi.org/10.5539/ies.v5n2p216
}

This research is financed by Hebei United University No.Q0938-06

\begin{abstract}
Under the theoretical framework of needs analysis, this paper is aimed to give insights into the college business English learners' needs (including target situation needs, learning situation needs and present situation needs). The analysis of the research data has provided teachers insights into business English teaching related issues.
\end{abstract}

Keywords: Needs analysis, Target situation analysis, Learning situation analysis, Present situation analysis

\section{Introduction}

Needs analysis is the starting point of every course and is of utmost importance for ESP course design. Needs are classified as necessities, wants and lacks (Hutchinson and Waters, 1987, p. 55, cited in Tony Dudley-Evans and Maggie Jo St John, 1998, p. 123) ; objective and subjective or process-oriented or product-oriented (Brindley, 1989, cited in T Tony Dudley-Evans and Maggie Jo St John, 1998, p. 123); and perceived or felt (Berwick, 1989, p. 55, cited in Tony Dudley-Evans and Maggie Jo St John, 1998, p. 123). However, Tony Dudley-Evans and Maggie Jo St John (1998, P. 123), further divided it into three larger categories: a target situation analysis (TSA, including objective, perceived and product-oriented needs); a learning situation analysis (LSA, including subjective, felt and process-oriented needs); and a present situation analysis (PSA, including learners' present levels of knowledge and skills).

Needs analysis conducted before a course works for teachers in setting teaching goals, selecting teaching content and materials, and exploring approaches of teaching and learning. Besides, it is a learner-centered approach, which is believed to stimulate learners' interest of learning to a large extent and show respect to the active role of learners in processes of learning. Furthermore, courses which are based on the findings of pre-course needs analysis will surely meet the needs of both language learners and employers.

\section{The Design of the Study}

\subsection{Methodology}

This research is a survey study and the purpose is to examine the TSA, LSA and PSA of Business English learners in College. Questionnaire, coupled with interview is to be used as a major instrument for collecting the data needed. The questionnaires designed are directed at three groups of subjects, respectively, employers, college graduates who have more than one-year work experience in Business English, and learners of College Business English courses. Highly structured questionnaires with mostly closed questions, together with open-ended questions, post-survey interview and classroom observation have been adopted. Out of the 103 employers and 226 college graduates surveyed, respectively 100 and 220 validate questionnaires have been collected; in the 123 Business English course learners, there are 120 validate questionnaires.

\section{Data Analysis}

\subsection{Target Situation Analysis}

What aspects of Business English are more practical and urgent in real work situations? Based on the analysis on the data obtained from following Questions, we can see learners' TSA clearly.

Question 1: Which of the following micro Business English skills are more practical? (Three choices) 

A. Telephone English
B. Business English negotiation
C. Products presentation
D. Conference English
E. Business English conversations
F. English contracts
G. Business English correspondences
H. Product instructions
I. Business English translation

Question 2: Which of the following certificates are attached much importance in job application? (Exclusive choice)
A. BEC certificates for intermediate or upper-intermediate levels
B. CET-4, CET-6 or EMT-8 certificate
C. Intermediate-level or Advanced-level English Interpreter Certificate
D. Dan Zhengyuan National International Business Licenses
E. Documents Operator Certificate

The data (see Table 1-2) collected indicate that most of the employers agree that business English conversation $(65 \%)$, business English negotiation $(50 \%)$ and product presentation $(50 \%)$ are the top three micro skills that should be attached greater importance to; the majority of college graduates give higher priority to business English conversation (72.7\%\%), business English negotiation (72.7\%) and business English correspondences (40.9\%). College undergraduates consider that business conversations (63.3\%), business English negotiations (56.7\%) and business English correspondences (45\%) are of much importance. A conclusion can be drawn that the three groups of subjects put business conversation and business English negotiation the first, therefore, the Business English course should focus on the two micro-skills.

As to which certificates are more useful, the data collected imply that $75 \%$ of employers, $68.2 \%$ of graduates and $56.7 \%$ of college students claim that CET- 4 or CET-6 or EMT- 8 certificate is necessary. $50 \%$ of the employers and $45.5 \%$ of graduates prefer Intermediate-level or Advanced-level English Interpreter Certificate. However, 45\% of college students think having a BEC certificate is very essential, which proves that they are misled due to lacking work experience.

\subsection{Learning Situation Analysis}

By researching on learners' motivation (Q3), and interest (Q4 \& 5), researchers work out learners' subjective needs.

Q3: Why do you select College Business English course? (Multiple choices)
A. out of personal interest
B. to prepare myself for business English certificates
C. in consideration to job-hunting
D. for credits
E. to prepare myself for overseas study

Q4 : What kind of business textbooks interests you most? (Exclusive choice)
A. Chinese business textbooks
B. Overseas Business English textbooks
C. Business English textbooks concerning learners' real needs
Q5: Which of the following ways of teaching do you like most? (Exclusive choice)
A. Business-English-knowledge-oriented teaching
B. Business-English-language-skill-oriented teaching
C. The mixture of both

From the data (See Table 3-5) collected we can see that $65 \%$ of the students select the course in consideration of 
job-hunting, $39.2 \%$ of them are out of personal interest. The minority of students is for acquiring credits (15\%), exam-driven (10.8\%) and overseas study (10.8\%). $70.8 \%$ of the students are in favor of Business English textbooks concerning learners' real needs. All of the students like business English course focused on both knowledge and skills.

\subsection{Present Situation Analysis}

The questions about the extent of the satisfaction of employers (Q6), and their observation of graduates' lacks in real work situation (Q7), coupled with graduates' and college undergraduates self-perception of the most difficult business English skills (Q8)and biggest obstacle(9) to their progress can be useful in finding out the lacks of learners.

Q6: To what extent are you satisfied with college graduates in terms of their business English knowledge and skills? (Exclusive choice)
A. extremely satisfied
B. satisfied comparatively
C. satisfied in general
D. not satisfied at all

Q7: What aspects of business English knowledge or skills do you think graduates are lacking in? (Multiple choices)
A. Business professional knowledge
B. Business English listening and speaking
C. Business English reading
D. Business English writing
E. Business English translating and interpreting

Q8: Which of the following do you think is the most difficult to master? (Exclusive choice)
A. Business professional knowledge
B. Business English listening and speaking
C. Business English reading
D. Business English writing
E. Business English translating and interpreting

Q9: What do you think is the biggest obstacle to you in business English? (Multiple choices)
A. A shortage of suitable textbooks or materials
B. A shortage of teachers expertise in both business professional knowledge and business English
C. A shortage of enough practice

The data (See Table 6-8) collected indicate that most of the employers (60\%) surveyed are satisfied in general with graduates. Only $5 \%$ are extremely satisfied. $70 \%$ of the employers think that graduates are especially lacking in business English listening and speaking. Merely 5\% of the employers feel that graduates are not good at business English reading; while all of the graduates consider that business English reading skills is not difficult to acquire. $35 \%$ of the employers observe that business English writing skills is another aspect which graduates lack; on the other hand, $22.7 \%$ of the graduates agree that it is not easy to master the writing skills. $70 \%$ of the employers claim graduates lacking in business English listening and speaking; while the majority of graduates (36.3) and college students(60.8) think that listening and speaking is the most difficult to master. As high as $75 \%$ of employers, $77.3 \%$ of graduates and $57.5 \%$ of college students consider a shortage of enough practice to be the biggest obstacle.

\section{Implications}

Based on the analysis of the results of the survey, college business English course should mainly focus on enhancing learners' business English listening and speaking. Materials that can best work for learners needs should be utilized. Task-based teaching approaches should be implemented, which can provide learners with enough practice and experience. Tasks should be selected from real work situation. Learners can be assigned to observe the real work situation and collect relevant information, materials and activities to compensate for the limit of classroom teaching. Besides pre-course needs analysis, during-course and post-course needs analysis should also be adopted to assess learners' progress and teaching efficiency. 


\section{References}

Adam, J. H. (1985). Longman Concise Dictionary of Business English. Harlow: Longman.

Berwick, R. (1989). Needs assessment in language programming: from theory to practice. In R. K. Johnson (Ed.). The Second Language Curriculum [M]. Cambridge University Press.

Brieger, N., \& J. Comfort. (1992). Language Reference for Business English. Hemel Hempstead: Prentice-Hall.

Brindley, G. P. (1989). The role of needs analysis in adult ESL programme design. In R. K. Johnson (Ed.) The Second Language Curriculum [M]. Cambridge University Press.

Cohen, L., Manion, L., \& Morrison, K. (2000). Research methods in education. London and New York: RoutledgeFalmer. http://dx.doi.org/10.4324/9780203224342

David Nunan. (2002). Research Methods in Language Learning [M]. Shanghai: Shanghai Foreign Language Education Press.

Dudley-Evans, T. (2001). English for specific purposes. In R.Carlter \& D.Nunan (Eds.), Teaching English to Speakers of other languages: A Cambridge Guide. (pp.131-136). Cambridge: Cambridge University Press. http://dx.doi.org/10.1017/CBO9780511667206.020

Dudley-Evans, T., \& St John, M. (1998). Developments in English for Specific Purposes. Cambridge: Cambridge University Press.

Huchinson, T., \& A. Waters. (1987). English for Specific Purposes. Cambridge: Cambridge University Press. http://dx.doi.org/10.1017/CBO9780511733031

Mark Ellis \& Christine Johnson. (1994). Teaching Business English. Oxford: Oxford University.

Nunan, D. (1988). Syllabus Design. Oxford: Oxford University.

Penny Ur. (2000). A Course in Language Teaching: Practice and theory [M]. Beijing: Foreign Language Teaching and Research Press.

R.R. Jordan. (1997). English for Academic Purposes: A guide and resource book for teachers [M]. Cambridge: Cambridge University Press. http://dx.doi.org/10.1017/CBO9780511733062

Tom H., \& Alan W. (1987). English for Specific Purposes: A learning-centered approach [M]. Cambridge: Cambridge University Press, 21-65.

Tony Dudley-Evans \& Maggie Jo St John. (1998). Developments in ESP: A multi-disciplinary approach [M]. Cambridge: Cambridge University Press, 121-140.

Young, J. (2000). Who needs analysis? ELT Journal, 54 (1), 72-74. http://dx.doi.org/10.1093/elt/54.1.72

Table 1. The data collected from responses to Question 1 Which of the following three micro Business English skills are more practical? (Three choices) $(\%)$

\begin{tabular}{|l|l|l|l|}
\hline \multicolumn{1}{|c|}{ Subjects } & Employers & College graduates & undergraduates \\
\hline A. Telephone English & & & \\
\hline B. Business English negotiation & 25 & 22.7 & 35 \\
\hline C. Product Presentation & 50 & 72.7 & 56.7 \\
\hline D. Conference English & 50 & 36.3 & 15 \\
\hline E. Business English Conversation & 5 & 4.5 & 25 \\
\hline F. English Contract & 65 & 72.7 & 63.3 \\
\hline G. English Correspondences & 10 & 9.1 & 5 \\
\hline H. Product Instruction & 40 & 40.9 & 45 \\
\hline I. Business English Translation & 0 & 13.6 & 10 \\
\hline & 5 & 9.1 & 15 \\
\hline
\end{tabular}


Table 2. The data collected from the responses to Question 2 Which of the following certificates are attached much importance in job application? (Exclusive choice) (\%)

\begin{tabular}{|l|l|l|l|}
\hline \multicolumn{1}{|c|}{ Subjects } & Employers & $\begin{array}{l}\text { College } \\
\text { graduates }\end{array}$ & undergraduates \\
\hline A. BEC certificates for intermediate or upper-intermediate levels & 20 & 18.2 & 40.5 \\
\hline B. CET-4, CET-6 or EMT-8 certificate & 75 & 68.2 & 56.7 \\
\hline $\begin{array}{l}\text { C. Intermediate-level or Advanced-level English Interpreter } \\
\text { Certificate }\end{array}$ & 50 & 45.5 & 35.8 \\
\hline D. Dan Zhengyuan National International Business Licenses & 35 & 31.8 & 25 \\
\hline E. Document Operator Certificate & 25 & 22.7 & 10 \\
\hline
\end{tabular}

Table 3. The data collected from the responses to Question 3Why do you select College Business English course? (Multiple choices) (\%)

\begin{tabular}{|l|l|}
\hline \multicolumn{1}{|c|}{ Subjects } & College Undergraduates \\
\hline Reasons & 39.2 \\
\hline B. Out of personal interest & 21.7 \\
\hline C. In consideration to job-hunting & 65 \\
\hline D. For credits & 15 \\
\hline E. To prepare myself for overseas study & 10.8 \\
\hline
\end{tabular}

Table 4. The data collected from the responses to Question 4 What kind of business textbooks interest you most? (Exclusive choice) (\%)

\begin{tabular}{|l|l|}
\hline \multicolumn{1}{|c|}{ Subjects } & College Undergraduates \\
\hline Aypes of Textbooks Chinese Business Textbooks & 7.5 \\
\hline B. Overseas Business English Textbooks & 21.7 \\
\hline C. Business English Textbooks Concerning Learners' Real Needs & 70.8 \\
\hline
\end{tabular}

Table 5. The data collected from the responses to Question 5Which of the following ways of teaching do you like most? (Exclusive choice) (\%)

\begin{tabular}{|l|l|}
\hline \multicolumn{1}{|c|}{ Subjects } & College Undergraduates \\
\hline A. Buss of Teaching $\quad$ Business-English-knowledge-oriented teaching & 0 \\
\hline B. Business-English-language-skill-oriented teaching & 0 \\
\hline C. The mixture of both & 100 \\
\hline
\end{tabular}


Table 6. The data collected from the responses to Question 6 To what extent are you satisfied with college graduates in terms of their business English knowledge and skills? (Exclusive choice) (\%)

\begin{tabular}{|l|l|}
\hline \multicolumn{1}{|c|}{ Subjects } & Employers \\
\hline A. Extremely satisfied & 5 \\
\hline B. Satisfied comparatively & 30 \\
\hline C. Satisfied in general & 60 \\
\hline D. Not satisfied at All & 5 \\
\hline
\end{tabular}

Table 7. The data collected from the responses to Question 7 What aspects of business English knowledge or skills do you think graduates are lacking in? (Multiple choices) and Question 8Which of the following do you think is the most difficult to master? (Exclusive choice) (\%)

\begin{tabular}{|l|l|l|l|}
\hline The Skills Required & Employers & College Graduates & Undergraduates \\
\hline A. Business Professional Knowledge & 25 & 13.6 & 4.2 \\
\hline B. Business English Listening and Speaking & 70 & 36.3 & 60.8 \\
\hline C. Business English Reading & 5 & 0 & 0 \\
\hline D. Business English Writing & 35 & 22.7 & 18.3 \\
\hline E. Business English Translating and Interpreting & 215 & 27.3 & 16.7 \\
\hline
\end{tabular}

Table 8. The data collected from the responses to Question 9: What do you think is the biggest obstacle to you in business English? (Multiple choices) (\%)

\begin{tabular}{|l|l|l|l|}
\hline \multicolumn{1}{|c|}{ Subjects } & Employers & $\begin{array}{l}\text { College } \\
\text { Graduates }\end{array}$ & Undergraduates \\
\hline Abstacles in Learning & 5 & 13.6 & 3.3 \\
\hline $\begin{array}{l}\text { B. A Shortage of Suitable Textbooks or Materials } \\
\text { Knowledge and Business English }\end{array}$ & 75 & 77.3 & 7.5 \\
\hline C. A shortage of Enough Practice & 20.7 & 57.5 \\
\hline
\end{tabular}

